
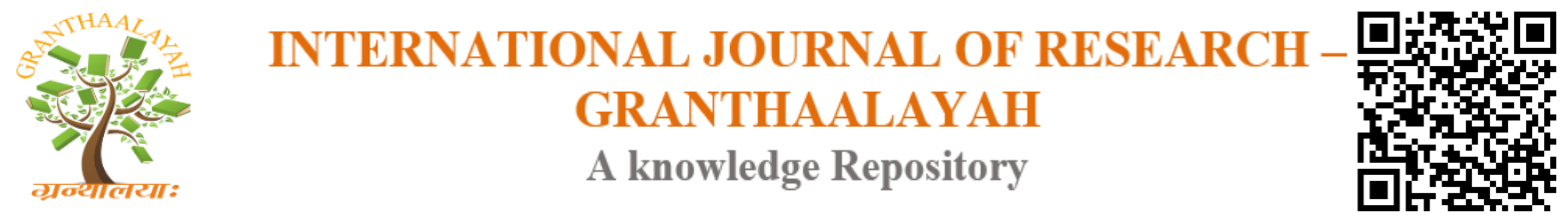

Management

\title{
ASSESSMENTS OF THE DETERMINANTS OF INVESTMENT ACTIVITIES IN NEKEMTE TOWN
}

\author{
Tesfaye Eresso Gofe *1 \\ ${ }^{* 1}$ Lecturer, Department of Accounting and Finance; College of Business and Economics; \\ Wollega University; Ethiopia
}

\begin{abstract}
Investment activity plays a crucial role in the economic growth of a country. Economic literatures show that investment is, both empirically and theoretically, the key determinant to economic growth. Investment can increase a country's productive capacity, provided that investment expenditure regards durable goods that have comparatively long useful lives and embody the latest technological advances. Economic growth refers to an increase in a country's production or income per capita. The study assessed the determinants of investment activities in Nekemte town which is found in Oromia region with $328 \mathrm{~km}$ away from Addis Ababa the capital city of Ethiopia. The research was investigated the major determinants of investment activities in the town and indicates the direction for investment how to deal with those determinants. For this study both primary and secondary data were used. Because of the heterogeneity of the activities the researcher was used stratified sampling techniques and the sample size was computed using solvin's formula. In this research the descriptive analysis was employed. Some of the main findings of the study were difficulties of finance and lack of credits when they started their business, and low encouragement from the investment offices are the major findings of this study.

Finally, investment related problem is not the responsibility of the government alone, but also all investors, the local community, the private business man of the town has to work together with the government so as to attain the desired objectives.
\end{abstract}

Keywords: Investment; Investment Activity; Determinants.

Cite This Article: Tesfaye Eresso Gofe. (2018). "ASSESSMENTS OF THE DETERMINANTS OF INVESTMENT ACTIVITIES IN NEKEMTE TOWN.” International Journal of Research - Granthaalayah, 6(11), 366-383. https://doi.org/10.29121/granthaalayah.v6.i11.2018.1140.

\section{Introduction}

Economic literatures show that investment is, both empirically and theoretically, the key determinant to economic growth. Economic growth refers to an increase in a country's production or income per capita. It is usually measured by gross national product or gross national income, used interchangeably, an economy's total output of goods and services. Investment is the source of manufactured goods that will be used to produce other goods. It is the major foundation of 
enhancement in the level of literacy, improvement in technology and increase in the capital stock (Hashmi et al 2012).

A rate of investment is one of the key factors that differentiate developed countries from developing countries. In high-growth countries investment is high, where as it is low in low growth countries. The implication of low investment is that the productive capacity of the economy fails to increase. This in turn leads to lower rates of growth and job creation, and fewer opportunities for the poor to improve their livelihoods (White, 2005). According to Sackey 2007, countries with high standards of living are those who have shifted the economic structure from traditional and less diversified to a more diversified one. Commitment to investment is the central issue in the process of structural diversification.

Economic growth has a long been one of primary goals in virtually every country of the world weather developed or developing. To this end capital formation, proper mobilization and allocation of resources and reduction unutilized resources to the productive sector of the economy is very crucial. Growth requires investment of both domestic and foreign, both public and private calls for increased domestic mobilization. (Todaro, 2005).

Investment activity plays a crucial role in the economic growth of a country. Investment can increase a country's productive capacity, provided that investment expenditure regards durable goods that have comparatively long useful lives and embody the latest technological advances. In addition, changes in investment expenditure can potentially result in shifts in the level of employment and personal income by affecting the demand for capital goods. Although gross fixed capital formation usually represents a substantially smaller fraction of an economy's total expenditure compared to consumption expenditure, it is a highly volatile component that causes strong fluctuations to a country's economic activity (Olga Kosma, 2015).

According to Keynes (1964) cited in Olga Kosma, (2015), investment is volatile because it is determined by the "animal spirits" of investors (optimism and pessimism). Furthermore, investment creates new capital goods so it is a very important determinant of an economy's longrun productive capacity, in the sense that a higher investment rate suggests that capital stock is growing rapidly.

According to Bahar Bayraktar Economic growth and development depend essentially on a country's ability to invest and make efficient and productive use of its resources. In this regard, the role of the private sector is important both in terms of its contribution to the quantity of Gross domestic investment and its ability to allocate and employ resources efficiently. (Bahar Bayraktar, 2003). Briefly, there cannot be growth without investment of sufficient amount and quality. In fact, investment is both a result and cause of economic growth.

Therefore, it is important to examine the main determinants of investment activities. Based on the literature review, this study has identified both dependent and independent variables. It is expected that dependent variable is affected by multiple factors like economic, social, political, institutional, cultural, geographical and etc. This study, however, focuses on macroeconomic factors affecting private investment activities. 
The role of investment to the development of a nation is very large. Investment increases the productive capacity of an economy. It is a very important to utilize untapped resource to create job opportunity for citizen, to increase foreign currency through import substitution and export promotion of a nation and facilitate the communication and cultural exchange of society.

Investment is critical determinant of a long run economics performance. Investment involves the formation of capital, fixed capital, such as reputation or technical knowledge; human capital such as: skill or education (Bond and Jan king 1996).

The investment sector is the main engine of growth in market economy. It thrives and delivers sustained growth when number of factor combines to product conductive environment for the investment sector to develop (Blejer \& khan, 2004). Investment played a great role in country's development especially in developing country whose capital is scarce and their government lack of enough capacity to cover all constrain and bring economic change for development (Asmelash, 2007). Thus, investment sector involved in investment the out and growth domestic product (GDP) country increase (Hernadeze-cata, 2000).

One of which could be promoting demand countries have shown that growth the economic have come through increased investment. Thus, investment play a vital role for economic growth and development and for improving the welfare of the society recent studies (collier gunning, 1999; dikumana, 2000; Hernadeze-cata, 2000) conducted has established the critical linkage between investment and the rate of economic growth.

Ethiopia is known with ancient civilization, historical culture, proud of tradition and on the top of all the land with immense potential for economic development of a country .The country is rich in natural resource and human resource. The climate and fertile soil are suitable for the cultivation of wide ranges of crops and live stocks. But this land of plenty is also suffering from poverty, lack of infrastructure, under development health center and fundamental ills of the economy system and reacts up on to keep the country under development.

Nekemte town's people almost reflect the real situations of a country in Ethiopia. The town has abundant natural and human resources. It is the habitual of various location of best kept secret of tourism site. It is natural resource such as mineral, forest, energy and diversified of climatic conditions, geographical area of the town hold the interest of the investors.

For developing countries like Ethiopia the basic question in their economy is increase the production and hence improve the standard of living of their people so that there will be dramatic change in their economic, political and social conditions. For this purpose different alternatives are on the table. Investment promotion is one key instrument and primary engine of economic growth (Mustefa, 2014). As a result due attention has been given to development of private sector in developing countries to help improve economic growth (Ouattara, 2004).

Understanding the status and determinants of private investment activities is essential for successful and effective implementation of sustainable development goals 
As investment plays a great role in economic development, the government of Ethiopia has given emphasis concerning this activity. Its purpose was to develop the investment activity by giving major incentives for investors and promotion of investment opportunities both for domestic and foreign investor so as to increase the number of participants in this activity. But due to social, political \& economic constraints this activity has not shown a remarkable development in the town.

Some research findings on promotion of the determinants of investment activities is concluded that, investment is constrained by the interest rate and individual demand determination, human capital base weaker and less diversified economy.

Different researches were conducted on the area of determinants of investment activity. The study done by Belay focuses on bureaucracy related problem, power supplies as factors that determine investment activity (Belay Kucchi, 2005). Similarly the research under taken by Gatberuach (2015) finds factors that determine the investment activity are investment incentive, and interest rate. Though there are many factors that determine the investment activities this study would be conducted by taking some factors such as economic factors, socio cultural factors, political factors, corruption, institutional problem like land holding policy, lack of advisory. Thus, this study is conducted to identify determinants of investment activity particularly in Nekemte town.

The study attempts to address the question of what really motivate individuals or organizations to invest in Nekemte. According to Edwin, et al. (2006), it is when individuals and organizations anticipate future cash needs, and expect that their earnings in the future will not meet those needs, that they take a decision to invest and make their money grow. However, before they decide as to where they think they will put their money to grow, they take into account numerous factors and these are the factors that this study attempts to identify.

The objective of the study is to identify the determinants of investment activities in the Nekemte town. The specific objective of the study is focused on the following:

- To identify Investments activities mostly involved in the town.

- To identify the major factors of investment activities in the town and examine how this factors affect the investment.

To identify the major investment activities obstacles and opportunities in the town

With the above objectives, this research paper answers the following general questions, which are useful in identifying the determinants and opportunities of investment activities in Nekemte town:

- What types of investment activities involved mostly in the town and why?

- What are the major factors that determine investment activities?

- What are the major investment activities obstacles and opportunities in the town?

This research paper may enrich the knowledge of the reader on the determinants of investment activities. It may add to the existing literature and serve as an additional source of reference. This paper also has the significance in initiating researchers to study the problem in depth, so that the researchers and readers understand the determinants and opportunities of investment in the town. 


\section{Literature Review}

Many scholars and academicians have defined the term of investment differently. According to Mankiew investment is defined as spending today for future benefits and it's the component of national income that links with future". (Mankiew, 2002)

Investment has been viewed and defined by different ways. It has different meaning in finance and economics. In economics investment is related to saving and deferring consumption it involved in many areas of the economy, such as business management and finance whether for households, firms or government. In finance investment is putting money into something with the expectation of gain, usually over a longer term. The term investment refers to a sum of funds committed on the physical and human cavity by both profit and no profit oriented individuals and institutions. It is applied to production of goods not meant for immediate consumption but further production of goods such goods are called, investment goods. The investment of business firms usually comprises of capital goods and inventories (Baddely, 2005).

According to Dr. Mohammad, Investment is the flow of capital which is used for productive purposes. There is a great emphasis on investment for being the primary instrument of economic growth and development for a country. Investment means an increase in capital spending and it helps in creating a robust economy (Dr. Mohammad Shafi, 2014). In economics, investment can be defined as the purchase of plant, equipment or inventory. In lay terms investment is the acquisition of an asset such as a stock or a bond.

Once an individual receives income, there are two alternatives to spend or to save it. Regardless of how you use your income, investment can be defined as postponed consumption. Individuals may postpone their current consumption to accumulate for the sake of accumulating. For any or all of these reasons individuals save part of their income rather than spend all of their income.

The above analysis shows that investment has a strong relationship with saves income. But the extent of investment also depends on the level of consumption. As Mayra observes "there are no other road of economic development than a compulsory rise in the share of the nation's income which is withheld from consumption. In an economy where living standard of the masses are too low, to curb consumption, it is difficult to mobilize and allocate resource in to investment activity. (mayrad,2003).

As investment activity is affected by social, political and economic condition, there are some criteria have to be considered before starting investment activity. It is obvious that before starting investment activity, one investor must know and analyze in what area he is going to invest, the available funds he/she has for investment, the economic and political situations and profitability. In addition, an investor should know the advantage for the society. That is the quality and quantity of goods and service to be produced, employment, export and utilization of natural resources.

In Ethiopia foreign and direct investment has been steadily growth the federal and regional government encourage investment: they provide land incentive such as; tax holding, an improved bureaucracy at the federal and regional investment office. The Ethiopian government special focus on investment and private investors both Ethiopian and non-Ethiopian national undertaken 
investment activities in the agriculture, construction and manufacturing sectors, flower farm, cement factory, steel melting and rolling mills are becomes more and more common in Ethiopia. Investment is the current commitment of dollar (birr) for period of time in order to drive further payments that will compensate the investors: the time the funds are committed, the expected rate of inflation and the uncertainty of the future payment

From this we can answer the question about why people invest and what they want from their investments. They invest to earn a return either income or capital appreciation from saving due to their deferred consumption. Investment emphasis to the capital to be used for investment as well as the risk associated with investment in two ways. The first one is Investment is the commitment of funds with the view to minimize risk and safeguarding capital while earning return (investment constructed with speculation). The other one is investment is the commitment of something other than money to a long or term interest or project (Caves 1993).

In modern changing economic nature and scope it is defined by the agreement of the association of south. East Asian nations (ASENS) given due emphasis to its scope as the term investment every find of asset and in particulate shall include through of exclusively.

In other words investment can be showed as: Movable and immovable property and any other property right such as mortgage liens and pledges; Shares, stocks and debentures of companies or interest in the property in such companies; Claim to money or any performance under contract having a financial value and intellectual property right and good will; Business concession conferred by law or under contract including concession to reach for, cultivate, extract or exploit natural resources (UNCTAD, Vol.11. 1999. P. 19)

\section{Element of Investment}

Element of investment are those which are common in investment activity. These are return, risk and time. Return refers to reward from investment which includes currently income, capital gain or losses and profits. Risk is the change when the expected or prospective again or profit less they expected outcomes is the degree of happiness of losses. Time is the important factor in investment is the time which offers different courses of action. As time move on analysis believe that conditions changes and investors revaluate expected return for each investment (Garagdhia and Babuks, 2003).

\section{Conceptual Framework}

What determine the level of investment are highly continuous and emphasized topics in economics. Investment spending depends on the economic, social and political situation of a country that affect the return, but such of favorable conditions is often lost for most developing countries in realizing this, there is a growing interest in the countries on the factors that influence the pattern of investment activity and some factors identified (Samuelson, 2004).

Investors invest more that will enable them to earn profit. According to him there are three main determinates. These are revenue that is an investment will bring more product which leads to encourage investors less and otherwise it discourage. The second one is cost which is interest rate and government taxes. As it is obvious investors invest by borrowing of funds and if the interest 
rate is higher it discourage investment. The third one is execration were the investors predict about the future return of investment and if its prediction is negative on its return this leads to discourage. (Samuel son, 2002)
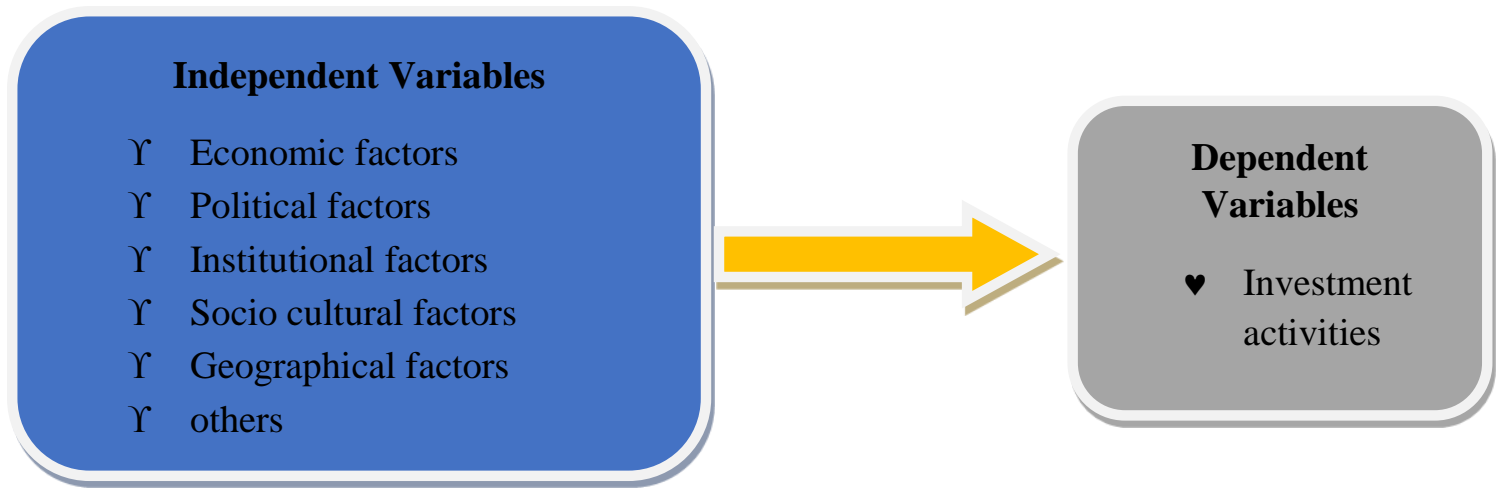

Source: literatures (conceptual framework)

Private investment is a major driver of economic growth. In LDCs, increasing the growth rate of private investment would be a desirable target to achieve development agenda of the country For this purpose policymakers need to find the right balance between creating a climate conducive to investment, removing barriers to investment and they need to find mechanisms to attract private investors.

It is important to examine the main determinants of private investment. Based on the literature review, this study has identified both dependent and independent variables. It is expected that dependent variable is affected by multiple factors like economic, social, political, institutional, cultural, geographical and etc. This study, however, focuses on macroeconomic factors affecting private investment ( Muhdin M. Batu, 2016).

Investment, as it has seen earlier, is an engine for economic growth and is one of the most important weapons in poverty alleviation. It improves the productive capacity of the nation and also creates job opportunity for many people. One of the most important components of investment is private investment in which business institutions engage in the production of goods and services with the twin objectives of profit maximization and improving national economy. That is why due attention has been given to private investment activities.

Different factors are expected to affect the performance of private investment activities, especially in the long run.

Muhidn M.Batu (2016) in his study determinants of private investment in Ethiopia concludes that investment is one of the key elements in economic growth and hence improving living standards of nations. A rate of investment is one of the key factors that differentiate developed countries from developing countries. Low investment leads to lower rates of growth and job creation, and fewer opportunities for the poor to improve their livelihoods. The primary objective of this study was to systematically review factors affecting private investment. For this purpose eleven studies were collected from nine African countries. 
The result shows that output/national income, public investment and exchange rate are the critical variables affecting the performance of private investment. The higher real GDP per capita is assumed increase effective demands for goods and services and thereby inspire private investors.

Public investment, in majority of the case, is seen a complement to private investment and hence promote private sector expansion and development. Exchange rate, like GDP and public investment, is important in the promotion of private investment. However, countries should take care in its management as its implication is in both directions: positive and negative.

The others variables: interest rate, credit, inflation rate, international trade, and money supply are also slightly important in explaining the performance of private investment.

In this regard, reasonable interest rate, broad money expansion and trade liberalization positively contributes to private investment. On the other hand, inflation and miss-targeted credit reduces private investment. Because of poverty, people, sometimes, would borrow to finance other matters like education, healthcare and basic necessities. The study finally recommends that countries should seriously work in creating enabling environment for private investment. To promote private sector investment, countries needs to improve real income of people; maintain macroeconomic stability and make public investment in basic infrastructures and institutions that are fundamental to promote private investment.

\section{Empirical Literature}

The empirical research on determinants of investment activity has in variably been limited in the developed country. However many studies have been made in developing country recently and have been conducted about the determinants of investment activity in different countries.

Corruption can be affect investment activity and there by lower the economic development (Mauro, 1995). Corruption is a specific measure of illegal activities with in the political system. The opportunity for corruption occurs when public officials are the gate keeper of public goods and services.

Shaum's (1999) has set the process for evaluation and selecting long term investment in long term asset such as property, plant and equipment or resource commitments in the form of new product development, market research, refunding and replacement decisions such as replacement of existing facilities with new facilities

Daniel (2004) has tried to model the determinant of investment activity in Ethiopia following the argument that investment is externally constrained in developing countries and it is affected by risk and unattained variables. The model tries to determining the investment activity, effects of external financial constraints domestic and international risk variables, public investment of infrastructure and out on the private investment. In this research we are concluded the determinants of investment activity by availability of finance, the real exchange rate, investment policy, debt service payment and the debt over hanging. 
It is important to examine the main determinants of private investment. Based on the literature review, this study has identified both dependent and independent variables. It is expected that dependent variable is affected by multiple factors like economic, social, political, institutional, cultural, geographical and etc. This study, however, focuses on macroeconomic factors affecting private investment.

Understanding the status and determinants of private investment is essential for successful and effective implementation of sustainable development goals (M. Muhammed hussen Batu, 2016).

\section{Research Methodology}

This study was conducted in one of the urban center, Nekemte town, which is located in East Wollega. The town is established long years ago. But still the investment activity is in its infancy stage. Nekemte town has vast natural resources and good climatic condition which indicates the relative advantage for the potential investment opportunities.

The town was considered to be the middle route to almost every districts, town and Regional Ethiopia. But due to economic, social and political constraints, the investment activity has not shown a considerable development.

Now a day the town has its own investment offices to encourage private inventors and foreign investors through giving major incentives to potential investors and promotional activities about investment opportunity in the town. The investment office is also responsible to facilitate infra structural facility for investment activities, about marketability of project, technical and advisory service to investors. But due to problems both on activities investors and government side, the investment activity in the town is very limited.

The study was descriptive and carried out using both primary and secondary data. Primary data was collected through structural questionnaires distributed to individuals who engaged in investment activity in the town and oral questions for the managers of Nekemte investment office. Secondary data was gathered from documents, reports books, magazines, internet and manuals.

The target population for this study was individual investor's and government organization of the town who give important information about the investment.

The town has 273 investors who are investing permanently in the town and out of these investors the researcher was selected 73 investor who represent the other else and to fill the questionnaires for data collection purpose by using Slovin's Formula, which is written as $\mathrm{n}=\mathrm{N} /\left(1+\mathrm{Ne}^{2}\right)$ where $\mathrm{n}=$ Number of samples, $\mathrm{N}=$ Total population and $\mathrm{e}=$ Error tolerance

Therefore, the Slovin's formula was employed to find the sample size.

$$
n=\frac{N}{1+N(e)^{2}}
$$

Where $\quad$ N=total population (investors) $=273$

$\mathrm{n}=$ the required sample size $=73$

$\mathrm{e}=$ merging error $(100 \%-90 \%)$ 


$$
\begin{gathered}
n=\frac{273}{1+273(0.1)^{2}} \\
n=73
\end{gathered}
$$

Therefore 73 investors were selected

$\mathrm{RR}=$ ratio sample size to total population

Therefore sample size from each sector can be determined proportionally as follow $\mathrm{RR}=\frac{n}{N}$
$\mathrm{RR}=\frac{73}{273}=0.27=27 \%$;
Agriculture $=10 * \frac{27}{100}=3$
Education $=19 * \frac{27}{100}=5$;
Health $=13 * \frac{27}{100}=3$
Trade $=172 * \frac{27}{100}=46$
Hotel and tourism $=59 * \frac{27}{100}=16$

Total $=73$

\begin{tabular}{|l|l|l|}
\hline Types of investment activities & No of population & Sample size \\
\hline Agriculture & 10 & 3 \\
\hline Education & 19 & 5 \\
\hline Health & 13 & 3 \\
\hline Trade & 172 & 46 \\
\hline Hotel and tourism & 59 & 10 \\
\hline Total & $\mathbf{2 7 3}$ & $\mathbf{7 3}$ \\
\hline
\end{tabular}

The designed questionnaires were distributed to the computed sample size in order to gather the needed information and since investors of the town are not homogeneous, stratified sampling techniques were used for the selection of typical sample out of the total population of investors. After collected necessary data the researcher was classified, analyzed and summarized the data in order to give meaningful results. The simple descriptive analysis was used because of its simplicity and clarity for drawing inferences.

\section{Results and Discussions}

This section deals with the analysis and discussion of the results from individual investors in the town. Regarding questionnaires, the researcher designed a questionnaire and distributed them to the total samples that are found at different age, education level and marital status and the researcher collected all of the questionnaires distributed to the respondents and all questionnaires were properly filled as well as give the necessary information for the researcher.

The personal characteristics and basic information of the study reveals that the women participation in investment activities are very low because of culture and traditional beloved particular in the town and generally in the country as a whole. 


\subsection{Present Investments and Their Problems}

Types of investment currently engaged

\begin{tabular}{|c|c|c|c|}
\hline Question raised & Alternative offered & No of respondents & Percentage \\
\hline In which type of & Hotel & 16 & $21.92 \%$ \\
\hline investment are you & trade & 45 & $61.64 \%$ \\
\hline engaged currently? & Agricultural & 4 & $5.48 \%$ \\
\hline & Health & 3 & $4.11 \%$ \\
\hline & Education & 5 & $6.85 \%$ \\
\hline & Total & 73 & $100 \%$ \\
\hline
\end{tabular}

The finding shows that $21.92 \%$ engaged in Hotel, $61.64 \%$ investors were engaged in trade, $5.48 \%$ investors were engaged agriculture, $4.11 \%$ investors engaged in health6.85\% investors were engaged education. From the types of investment currently engaged in the town most of the investors engaged in service sector.

Investment response to the problem they faced

\begin{tabular}{|c|c|c|c|}
\hline $\begin{array}{l}\text { What types of economic factor you faced } \\
\text { during your engagement? }\end{array}$ & $\begin{array}{l}\text { Lack of capital } \\
\text { Rate of taxation } \\
\text { Infrastructural facilities(water, } \\
\text { Road, Electricity and } \\
\text { Communication services) } \\
\text { Total }\end{array}$ & $\frac{33}{73}$ & $\frac{45.20 \%}{100 \%}$ \\
\hline $\begin{array}{l}\text { What types of social awareness \& initiative } \\
\text { problems you faced during you engagement? }\end{array}$ & $\begin{array}{l}\text { Lack of educational facilities } \\
\text { Lack of health facilities } \\
\text { Lack of social stabilities } \\
\text { Lack of social attitude towards } \\
\text { work } \\
\text { Expenditures behaviors } \\
\text { Total }\end{array}$ & $\begin{array}{l}20 \\
15 \\
25 \\
10 \\
\frac{3}{73}\end{array}$ & $\begin{array}{l}27.39 \% \\
20.55 \% \\
34.25 \% \\
13.69 \% \\
\frac{4.11 \%}{100 \%}\end{array}$ \\
\hline $\begin{array}{l}\text { What types of political factor you faced during } \\
\text { your engagement? }\end{array}$ & $\begin{array}{l}\text { Political participation in } \\
\text { decision making } \\
\text { Lack of women empowerment } \\
\text { Lack of good administrative } \\
\text { services } \\
\text { Corruption\& related issue } \\
\text { Land administration \& } \\
\text { management problem } \\
\text { Investment } \\
\text { \&administration problem } \\
\text { Total }\end{array}$ & $\begin{array}{l}10 \\
12 \\
18 \\
15 \\
10 \\
8 \\
73\end{array}$ & $\begin{array}{l}13.69 \% \\
16.44 \% \\
24.66 \% \\
20.55 \% \\
13.69 \% \\
10.96 \% \\
100 \%\end{array}$ \\
\hline $\begin{array}{l}\text { What types of Environmental factor you faced } \\
\text { during your engagement? }\end{array}$ & $\begin{array}{l}\text { Pollution } \\
\text { Seasonality } \\
\text { Land degradation } \\
\text { Waste management } \\
\text { Total }\end{array}$ & $\begin{array}{l}8 \\
42 \\
5 \\
\frac{18}{73} \\
\end{array}$ & $\begin{array}{l}10.96 \% \\
57.53 \% \\
6.85 \% \\
24.66 \% \\
100 \% \\
\end{array}$ \\
\hline
\end{tabular}


The above reveal that $27.39 \%$ of the respondents are replied lack of capital during their engagement in investment activities, $19.18 \%$ of the respondents are answered that rate of taxation during their engagement in investment and $45.20 \%$ of the respondents are answered lack of infrastructural facilities.

The finding shows that the majority of investors face the problem of infrastructural facilities during their engagement of investment activities.

Out of 73 respondents, $27.39 \%$ said lack of educational facilities, $20.55 \%$ said lack of health facilities, $34.25 \%$ said lack of social stability, $13.69 \%$ said lack of social attitude towards to work and $4.11 \%$ said expenditures behaviors face the investors during their engagement in the investment activities.

From the above information the researchers under stood that majority of investors face the problem of social stability during their engagement in the investment activities and relatively lack of educational facilities.

Out of 73 respondents, $13.69 \%$ said political participation in decision making, $16.44 \%$ said lack of women empowerment, $24.66 \%$ said lack of good administrative services, $20.55 \%$ said corruption and related issue $13.69 \%$ said land administration and management problem and $10.69 \%$ said investment policy and administration problem.

From the above information the researcher under stood that the majority of investors face the problem of corruption and related issue and land administration and management problem during their engagement in the investment activities.

From the total 73 respondents, $10.96 \%$ of the respondents said there is pollution problem, $57.53 \%$ of the respondents said there was seasonality problem, $6.85 \%$ of the respondents said there was the problem of land degradation and $24.66 \%$ of the respondents said there was waste management problem faced during their engagement in the investment activities.

From the above information the researchers conclude that the majority of problem that faced the investors are the seasonality problem and waste management problem that faced during their engagement in the investment activities.

In addition, investments significantly affect the intensity of overall economic activity and growth in general. Changes in size, structure and purpose of investment may indicate forthcoming conjuncture changes, but also longer-term developmental characteristics of the economy. Therefore, investment decisions are of special interest not only to policy makers and researchers, but also to firm managers and owners (M. Peric, J. Đurkin, 2015) 


\subsection{Sources of Finance and Investors Prospect}

Sources of data and accessibility of financial source

\begin{tabular}{|l|l|l|l|}
\hline Question raised & Alternative offered & No of respondents & Percentage \\
\hline What are your sources & Government bank & 20 & $27.39 \%$ \\
of fund to invest? & Private banks & 19 & $26.03 \%$ \\
& Credit and loan association & 25 & $34.25 \%$ \\
& Personal saving & 9 & $12.33 \%$ \\
& Total & 73 & $100 \%$ \\
\hline How do you rank the & Easy & 18 & $24.66 \%$ \\
accessibility of their & Difficult & 32 & $43.84 \%$ \\
financial soundness to & Medium & 23 & $31.50 \%$ \\
investors? & Total & 73 & $100 \%$ \\
\hline $\begin{array}{l}\text { What is your attitude } \\
\text { towards the current }\end{array}$ & Encourage & 49 & $67.12 \%$ \\
investment strategy of & Discourage & 24 & $32.88 \%$ \\
government in the & & & \\
study town? & Total & 73 & $100 \%$ \\
\hline $\begin{array}{l}\text { What means to get } \\
\text { information about the }\end{array}$ & News paper & 20 & $27.39 \%$ \\
areas of investment & Magazines & 15 & $20.55 \%$ \\
activities in the & Media & 26 & $35.62 \%$ \\
investment offices? & Documents & 12 & $16.44 \%$ \\
\hline
\end{tabular}

As the above table shows that most of respondents $34.25 \%$ used credit and loan association, $27.39 \%$ used government bank, 26.03\% used private banks and personal saving $15.33 \%$ used their own capital and borrowed from their families and friends. With regarding to accessibility condition of financial sources to investors from the financial institution, $24.66 \%$ of the respondents as easy, $43.84 \%$ of investors rank as Difficulties and $31.50 \%$ of respondents rank as Medium to get financial sources (funds) from financial institutions.

According to the views of the investors responded to the difficulties in using financial sources, the un-ability to meet collateral requirements, high interest rate, lack of long term and absence of financial intermediary are the most frequent reason for not obtain financial sources.

According to many investors ideas the current investment policy of the town is encouraging $69.12 \%$ of the respondents said that current investment policy of the town is encouraging if they compare with the previous investment policy of the town and $32.88 \%$ of the respondents said that the current investment policy of the town is discourage because of there is a discrimination and corruption is more involved in the investment activities of the town.

It also shows that $27.39 \%$ of the respondents are to get information about the areas of investment activities from the newspaper, $20.55 \%$ of the respondents are get information from the magazines, $35.66 \%$ of the respondents are get information from media and $16.44 \%$ of the respondents are get information from the documents 
Investor's future review

\begin{tabular}{|l|l|l|l|}
\hline Question raised & Alternative offered & No of respondents & Percentage \\
\hline Dou you have any plan to & Yes & 50 & $68.49 \%$ \\
start the investment activities? & No & 23 & $31.51 \%$ \\
& Total & 73 & $100 \%$ \\
\hline Is there any training program & Yes & 40 & $54.79 \%$ \\
related to the investment & No & 33 & $45.21 \%$ \\
activities? & Total & 73 & $100 \%$ \\
\hline Have you got any skill & Yes & 40 & $54.79 \%$ \\
training about investment & No & 33 & $45.21 \%$ \\
since you have started it? & Total & 73 & $100 \%$ \\
\hline
\end{tabular}

As the table of investors future review above shows $68.49 \%$ of the respondents have been plan to start in investment activities of the town. While only $31.51 \%$ of the respondents have no plan to start the investment activities of the town. This implies that most of the investors have plan to start to their business which seems to have positive relationship with capacity

The table shows $54.79 \%$ of the respondents have got training program related to investment activities. But $45.21 \%$ of the respondents have not any training program related to the investment activities. This implies that most of the investors have got training program to enhance the investment activities.

According to many investors ideas, most of them $54.79 \%$ skill development training about investment movement and how to manage their resources and how to minimize risk i.e. risk diversification in order to achieve their objective goals and $45.21 \%$ of the respondents did not get skill development training about investment before they had started the investment activities in the town because they haven't enough time to get skill development and nobody initiate them to participate on skill development training program.

As the view of the investors for encouraging nature of current investment policy, they argued that the policy had made efforts to improve the operating environments through serious problems of implementation limits the benefits of the policy. However, others considered if as discover aging because of enormous practical problems of the policy rather than the theoretical attractiveness of the policy. One can see from the study that most investors have good attitude to the theoretical design of the policy than what practically have been done in implementing it.

In other words the current investment policy have got theoretical acceptance by most of investors, though it has serious problems of implementation that discouraged investors. This leads us to the conclusion that the current investment policy would be more import and through giving emphasis is to the implementation of the policy from work. As investors suggested the government and investors should express their interest too jointly work together to identify constrains and examines solution for lack of properly implementing policy.

To sum up, most investors have many problems regarding source of funds to invest, political instability, corruption, inaccessibility of financial resources, economic, lack of infrastructure and tax levied on the investors of the town. 


\subsection{Summary of the Types of Investment Activity in the Nekemte Town}

There are different types of investment activity; those are agriculture, Education, health, trade and hotel and tourism sectors. This classification is presented in the following table with their respective number of members and job created by them.

Types of profile investment activities in Nekemte town

\begin{tabular}{|c|c|c|c|c|c|c|c|c|}
\hline \multirow{2}{*}{$\begin{array}{c}\text { Investment } \\
\text { type }\end{array}$} & \multicolumn{7}{|c|}{ Sub-city } & \multirow[b]{2}{*}{$\begin{array}{c}\text { Percentage } \\
(\%)\end{array}$} \\
\hline & Chalalki & Darge & Kaso & $\begin{array}{c}\text { Baknisa } \\
\text { kase }\end{array}$ & $\begin{array}{c}\text { Burka } \\
\text { Jato }\end{array}$ & $\begin{array}{l}\text { Bake } \\
\text { jama }\end{array}$ & Total & \\
\hline Agriculture & 4 & 1 & - & 2 & 1 & - & 8 & 2.93 \\
\hline education & 6 & 2 & 4 & 1 & 4 & 2 & 19 & 6.96 \\
\hline health & 5 & 1 & 3 & 2 & 1 & 1 & 13 & 4.76 \\
\hline trade & 56 & 22 & 32 & 18 & 12 & 34 & 174 & 63.74 \\
\hline $\begin{array}{l}\text { Hotel and } \\
\text { tourism }\end{array}$ & 20 & 5 & 10 & 11 & 4 & 9 & 59 & 21.61 \\
\hline Total & 91 & 30 & 49 & 34 & 20 & 46 & 273 & 100 \\
\hline
\end{tabular}

According the table in Nekemte town there are five investment activities, those are classified in to two major investment activities. Thus sectors are agriculture and service sectors. The agriculture which contributes to $2.93 \%$ of the total investment activity and it is contributed lowest when compared the other sector. The second sector is service sector which is contributed the largest total investment when compared with the rest one which is $33.33 \%$. In generally in Chalalaki sub-city there are 91 investment activities, in Darge 30 types of investment activities, Kaso 49 types of investment activity, in Bakenisa kase sub city there are 34 investment activities, in Burkajato there are 20 investment activities and in Bake jama there are 46 investment activities.

\section{Conclusion and Recommendations}

Investment is one of the key elements in economic growth and hence improving living standards of nations. A rate of investment is one of the key factors that differentiate developed countries from developing countries. Low investment leads to lower rates of growth and job creation, and fewer opportunities for the poor to improve their livelihoods.

The primary objective of this study was to systematically review factors affecting investment activities. In this area different studies were conducted over the world and also even particularly in Ethiopia. The result shows that output/national income, public investment and exchange rate are the critical variables affecting the performance of private investment. The higher real GDP per capita is assumed increase effective demands for goods and services and thereby inspire private investors.

Public investment, in majority of the case, is seen a complement to private investment and hence promote private sector expansion and development. Exchange rate, like GDP and public investment, is important in the promotion of private investment. However, countries should take care in its management as its implication is in both directions: positive and negative. 
Investment, as it has seen earlier, is an engine for economic growth and is one of the most important weapons in poverty alleviation. It improves the productive capacity of the nation and also creates job opportunity for many people. One of the most important components of investment is private investment in which business institutions engage in the production of goods and services with the twin objectives of profit maximization and improving national economy. That is why due attention has been given to investment activities. Different factors are expected to affect the performance of investment activities, especially in the long run.

For developing countries like Ethiopia the basic question in their economy is increase the production and hence improve the standard of living of their people so that there will be dramatic change in their economic, political and social conditions. Investment promotion is one key instrument and primary engine of economic growth (Mustefa, 2014). As a result due attention has been given to development of private sector in developing countries to help improve economic growth (Ouattara, 2004).

Reliable and continuous increase in domestic private investment also helps in reduction of poverty. Understanding the status and determinants of private investment is essential for successful and effective implementation of sustainable development goals.

Allocation of capital on different sectors of economic activity is essential to move the available resources in to more productive. To increase the development, allocation of human and natural resources in effective and efficient manner on investment activity is very crucial aspect. Without investment it is impossible to have any development rather it remains in poverty. This is mainly seen in developing countries like Ethiopia. If there is unemployment, there will be low productivity which results in low level of income, there is poverty.

This research is conducted in Nekemte town to investigate the factors that determine the determinants of investment activity. Data was collected through primary and secondary method. The data obtained was analyzed through descriptive method. According to data obtained shows that the investment activity was found in its low level to activity due to various a constraints. However, the town has good opportunity to become an important distribution center in East wollega zone. Owing to its strategic location due to its proximity to Addis Ababa and as a Junction point for roads that head to various directions.

Yet the level of investment activity in the town is rather small particularly when compared with the level of the investment in other small towns that recently gained a higher administrative status. Bureaucratic system of land lease policy has a great impact on investment activity.

Due to high competitions among investors, a small unit of land has high price in the town and it is difficult to get land easily for construction purpose. Low level of institutional capacity due to absence of well qualified workers to study investment opportunities in the town and to promote it to potential investors, to give advisory and incentives for investors would have its own limitation on this investment activity. The town's low level of infrastructure facilities like deteriorated and overcrowded roads, unbalance educational and health services with the town's population have also negative influence on investment activity. 
In general, the town has strategic location as a middle route with favorable climatic condition can be seen as an opportunity for development of new investment activity and due to economical, infrastructures and political hindrances this activity in its low of stage in the town.

\section{Recommendations}

Based on the finding the following suggestion is forwarded to improve the factors that determine the investment activities in the town and also to reduce or eliminate some problem faced by the investors. To enhance the investment activity in the town in the future, the following recommendations are suggested by the researcher.

- The main constraint for business activity in the town is the difficulty to easily obtain land for new investment. In this regard the land lease policy which is being used by the local authorities for implementation in the town should be handled in a manner that will contribute to the investment activities so that the investment may be enhanced which indirectly contribute to the economic growth of the country.

- Development of infrastructure facilities plays a major role for the development of investment activities. In order to facilitate transportation service, deteriorated roads should be maintained, gravel surface roads should be asphalted and the construction of additional inner roads which can help for fast movement of goods and service within the town.

- It is recommendable to diversify the business activities. To diversify the business activities, it is essential to provide sufficient information to private investors about alternative investment opportunities. In this regard, the institution capacity of the town should strengthen to give advisory and consultation service for potential investors before they start their investment activities by seeing only others investments so that they can easily identify the new investment activity in the town.

- It is recommendable to prepare land for investment with infrastructural facilities.

- The other thing is it is advisable to Expand loan institutions to increase the financial capacity of the investors and enhancing promotions for investment

- In addition it is advisable to provide different training, group discussions, seminars on various issues so as to avoid or minimize the corruption behavior of individual investors and the concerned offices.

Generally the researcher recommended that the government body should facilitate infrastructure and also to promote essential information to investors and should establish efficient advisory and consolation service.

\section{References}

[1] Agu, O. C. (2015). Determinants of Private Investment in Nigeria an Econometric Analysis. International Journal of Economics, Commerce and Management United Kingdom Vol. III, Issue 4.

[2] Ambachew Mekonnen, 2010; Determinants of private investment in Ethiopia: Ethiopian Journal of Economics, Volume XIX, No. 1

[3] Asmelash, B, 2007; Opportunities and Service Delivery of Investment, Msc Thesis, Addis Ababa University, Ethiopia.

[4] Bahar Bayraktar, 2003, The Role of private Sector investments in the economic performance of OIC member Countries; Journal of Economic Corporation 24, 1, 63-110

[5] Bond \& Jnkinson , 1996; Assessment Of Investment Performance And Policy, Oxford 
[6] Baddely M.C (2005), Investment Theories and Analysis, Grove Land College Cambridge.

[7] Brehanu, N. \& Befekadu, D. (2003/2004).Annual Report on Ethiopia Economy.Vol.3.Ethiopia Economic Association Press, Addis Abeba, Ethiopia.

[8] Blejer, M, \&Khan, M.S.(2004).Government Policy And Private Investment In Developing CountriesImf Working Papers, Washington Dc

[9] Collier, P, \& Gunning, J.W. (1999) Explaining American Economic Performance. Journal of Economic Literature, 37, 64-111.

[10] Dornbusch, R. \&Fishers, S. (1994) Microeconomic (6th Edition).New York: Mc Graw-Hill.

[11] Edwin J.E., et.al. (2006). Modern Portfolio theory and investment analysis. Yale school of management, Connecticut.

[12] Fisher (1994), Macroeconomics, the World Bank and Department, 6theduition, New York Universityand Population Council.

[13] Hernadeze-Cata, E. (2000) Raising Growth Of Private Investment In Sub Saharan Africa: What Can Be Done? Policy Discussion Paper of International Money Fund. Washington D.C

[14] Hashmi, M. H., Akram, W. and Hashmi, A. A. (2012). Role of Investment in the Course of Economic Growth in Pakistan. International Journal of Academic Research in Economics and Management Sciences September 2012, Vol. 1, No. 5 ISSN: 2226-3624.

[15] Keynes, John M. (1964), "The General Theory of Employment, Interest, and Money”. New York: Harcourt Brace.

[16] Makiw, (2002).Macroeconomics, fourth edition worth publisher, New York

[17] Mohammad Shafi, 2014, Determinants Influencing Individual Investor Behavior In Stock Market: A Cross Country Research Survey Arabian Journal of Business and Management Review (Nigerian Chapter) Vol.2, No. 1 Economic

[18] Mustefa, S. (2014). Private Investment and Economic growth Evidence from Ethiopia. A thesis Submitted in Partial Fulfillment of the requirements for Degree of Master of Science in Economics (Specialization in policy Analysis), Mekele University, Ethiopia.

[19] Muhdin Muhammedhussen Batu. Determinants of Private Investment: A Systematic Review. International Journal of Economics, Finance and Management Sciences. Vol. 4, No. 2, 2016, pp. 52-56. doi: 10.11648/j.jjefm.20160402.1

[20] M. Peric, J. Đurkin: Determinants Of Investment Decisions In A Crisis: Perspective Of Croatian Small Firms; Management, Vol. 20, 2015, 2, Pp. 115-133

[21] Olga Kosma; (2015) Determinants of Investment Activity: the Case of Greece ISSN: 2241-4851

[22] Ouattara, B. (2004). Modelling the Long Run Determinants of Private Investment in Senegal. CREDIT Research Paper No. 04/05.

[23] Samuel Son (1989) Consumption and Investment Economics 13thed.

[24] Serven L. And Anders Solimano (1991), Economic Adjustment and investment Developing Countries.

[25] Sackey, H. A. (2007). Private Investment for Structural Transformation and Growth in Africa: Where do Small and Medium-Sized Enterprises Stand? African Economic Conference 2007' Opportunities and Challenges of Development for Africa in the Global Arena 15-17 November 2007, Addis Ababa, Ethiopia.

[26] White, S. (2005). Enhancing private investment for development: Policy guidance for development agencies.

*Corresponding author.

E-mail address: tesfaye.eresso @yahoo.com. 